V. M. Molokanova ${ }^{1}$, Dr. Sc. (Tech.), Prof., orcid.org/0000-0002-4353-4948, O.P. Orliuk ${ }^{2}$, Acad. of the National Academy of Legal Sciences of Ukraine, Dr. Sc. (Jurid.), Prof., orcid.org/0000-0001-5145-5919,

V. O. Petrenko ${ }^{3}$, Dr. Sc. (Tech.), Prof., orcid.org/0000-0001-5017-1674,

O. B. Butnik-Syverskyi², Dr. Sc. (Econ.), Prof., orcid.org/0000-0003-2492-231X,

V. L. Khomenko ${ }^{4}$, Cand. Sc. (Tech.), Assoc. Prof., orcid.org/0000-0002-3607-5106
1 - Dnipropetrovsk Regional Institute of Public Administration of the National Academy of Public Administration under the President of Ukraine, Dnipro, Ukraine, e-mail: molokany@gmail.com

2 - Research Institute of Intellectual Property of the National Academy of Sciences of Ukraine, Kyiv, Ukraine, e-mail: e.orliyk@ndiiv.org.ua, busiv@ukr.net

3 - National Metallurgical Academy of Ukraine, Dnipro, Ukraine, e-mail: petrenko_v@email.ua

4 - Dnipro University of Technology, Dnipro, Ukraine, e-mail: inteldriller@gmail.com

\title{
FORMATION OF METALLURGICAL ENTERPRISE SUSTAINABLE DEVELOPMENT PORTFOLIO USING THE METHOD OF ANALYZING HIERARCHIES
}

Purpose. Formalization of the main stages and methods of project portfolio formation for a metallurgical enterprise, taking into account the strategy of its sustainable development.

Methodology. To characterize each element and the subsequent presentation of the corresponding weight indicator, based on which the selection of portfolio components will be performed, the classical method of hierarchy analysis is used. This method allows assessing the priorities of sustainable development of the enterprise relative to its general goal.

Findings. A development portfolio model has been presented that combines three elements in the interaction: economics, technology, and environmental analysis. Each of these elements is characterized by five criteria. Based on the hierarchy analysis method, it is reasonable to evaluate each of the potential components to justify their inclusion in the portfolio by integrated assessment. The sequence of stages of the methodology for selecting projects to the portfolio of sustainable development of a metallurgical enterprise is described. To determine the innovativeness of projects, criteria are proposed that characterize their suitability.

Originality. A fundamentally new model of the development portfolio has been proposed, combining three elements in the interaction: economy, technology and environmental analysis. For the first time, criteria have been proposed for determining the innovativeness of projects that characterize the suitability of technologies for the particularities of the enterprise. A new method of forming an enterprise development portfolio using the hierarchy analysis method is presented.

Practical value. As a result of the research to form the basis of project proposals, experimental training was conducted for midlevel personnel of a metallurgical enterprise. After conducting preliminary studies, a database of project proposals was formed for the sustainable development portfolio of the enterprise.

Keywords: sustainable development, metallurgical enterprise, project portfolio, a method of analyzing hierarchies

Introduction. The problem of sustainable development remains one of the most urgent for metallurgical enterprises. Rapid changes in the environment allow different development scenarios for the metal products market in the future. A practical solution to the problem of sustainable development of metallurgical enterprises in today's environment requires reducing energy costs and environmental pollution while maintaining production volumes. The state of metallurgical enterprises is such that it requires the implementation of not one, but several projects at the same time, and this in turn requires the proper prioritization of the projects in portfolio. Existing models and methods do not cover adequately all planning and managing problems of the enterprise sustainable development.

Literature review. In June 1992, at the United Nations Conference on Environment and Development, representatives of 178 states signed for the first time the Declaration of the Sustainable Development of Mankind in the face of an increasing rate of environmental change. In our country, on January 12, 2015, the Decree of the President of Ukraine "On the Strategy for Sustainable Development" Ukraine 2020" was signed, which defines the directions and priorities for the development of Ukraine for the period until 2020. "Strategy 2020 " consists of four movement vectors: sustainable development of the country; security of the state, business and citizens; responsibility and justice; pride for Ukraine in Europe and the world. In 2015, a special meeting of the UN General Assembly was held in New York, at which the official document of the

(C) Molokanova V.M., Orliuk O.P., Petrenko V.O., Butnik-Syverskyi O. B., Khomenko V. L., 2020 summit "Transforming the World: a Global Development Program until 2030" was adopted. This program contains 17 goals, 169 targets and a call to action in five key areas: people, the planet, financial well-being, peace and partnerships. In this regard, in 2017, a draft of the Strategy for Sustainable Development of Ukraine until 2030 was developed [1].

The signing of the Declaration laid the foundation for a scientific approach called "sustainable development", which allowed the professional literature to make a large number of generalizations regarding the proposed concept [2].

Sachs $\mathbf{J}$. argues that sustainable development is now so fundamental to our modern society that the principles of sustainability should become the norm for solving a wide range of global problems [3].

In [4], the basic imperatives and strategic directions of rationalization of all areas of resource using are formulated on the basis of the innovation-investment model. The methodological foundations of natural resource component capitalization of the socio-economic potential of sustainable development are disclosed in the conditions of power decentralization and strengthening of the European integration vector of Ukraine's development.

Analyzing the concept of sustainable development of mankind as a biosocial system, one should apply the well-known system law by which only the system in which all the basic elements and subsystems are also reliable and stable is stable and reliable [5].

Based on the concept of sustainable development, it can be argued that the sustainable development of any system should be provided by the following processes: 
- avoiding production activities based on irresponsible consumption and introducing flexible, highly professional management;

- creation of social conditions for cooperation of people in all spheres of activity on the basis of open dissemination of knowledge and skills;

- humanization of relations between people at all levels of social systems.

Although the basic principles of sustainable development are well developed in relation to social development, in the theory of development of organizations the methodology of sustainable development is still poorly developed. A review of the literature on the research topic showed that most often sustainable development is associated with innovative projects $[6,7]$. At the same time, innovative projects are considered as a sequential or parallel implementation of research, scientific, technical and industrial activities.

Sustainable development of the enterprise is the basis for the viability of its economic mechanism, both in the current period and in the forecast [8].

The specifics of sustainable development in the metallurgical industry is the subject of a number of publications.

Thus, when analyzing the issues of sustainable development in the mining and metallurgical sector of Poland in [9], it was concluded that the activities of management companies in the metallurgical and mining sectors should be aimed at regular updating, improvement and constant commitment to a dialogue with - by interested parties, documented in the form of reports on corporate social responsibility.

Sustainable development in industry should increase efficiency and reduce waste, find new production methods so that economic growth can be achieved with fewer natural resources, fewer materials, especially rare ones, with less energy consumption from traditional resources and with more efficient technologies with less negative impact on human health and the environment [10].

The work [11] is devoted to the diagnostics of the development of the metallurgical complex of the eastern regions of Ukraine. As a result of the analysis, it was concluded that the biggest problem with these enterprises is not the physical destruction of enterprises, but the rupture of production ties.

In work [12], modern challenges for metallurgical enterprises are highlighted: institutional, technological, competitive, and environmental.

In [13], to solve the problems of sustainable development of the mining and metallurgical complex of Ukraine, an economic and mathematical model was developed for the integrated formation of mining enterprises. This model is aimed at eliminating the monopoly dictate of the processor at purchase prices, provides mutually beneficial cooperation of partners, the effectiveness of which is determined by the scientifically substantiated limitations.

Another approach to ensure the sustainable development of metallurgical enterprises was proposed by the authors of the work [14]. It proposes to consider the process of strategic planning of a metallurgical enterprise as a dynamic set of interrelated management processes.

Unsolved aspects of the problem. The problem of ensuring sustainable development exists in almost every company, since the term "problem" in management practice is most often understood as "inconsistency of the current state with the desired". The logical-structural approach, which is used in the pre-investment phase of development portfolio management, recommends starting the analysis with the formation of a goal tree. The strategic management of the project portfolio is best suited to adapt the enterprise to environmental changes and the globalization of markets, but it also has significant theoretical gaps. Therefore, the systematization of scientific, theoretical and applied aspects of the implementation of portfoliooriented management is a topical issue in the theory and practice of project management.
Purpose. The purpose of the article is formalization of the main stages and methods of a projects portfolio forming for a metallurgical enterprise, taking into account the strategy of its sustainable development.

Methods. To achieve this goal, literary sources on sustainable development and project management were analyzed, Ukrainian and international laws on this topic were considered, and algorithmization was used to analyze the process of projects portfolio formation.

To characterize each element and the subsequent presentation of the corresponding weight-based indicator, on the basis of which the selection of portfolio components will be performed, the classical method of hierarchies analysis proposed by T. Saati is used. This method allows evaluating the priorities of sustainable development of the enterprise relative to its general purpose.

Results. In the international standards of project management, the management of projects, programs and portfolios formalized and the requirements for management processes defined. In this study, the terms and definitions are used in the PMI knowledge system and P2M, as well as key definitions of the ICB IPMA standard. Among the most significant trends in the development of project management is structuring project management in three management levels: a portfolio of projects, a program and individual project. To move the organization to a higher level of project maturity, one must understand the project hierarchy and the features of development management through projects.

The strategic objectives of the enterprise and the portfolio of projects are inextricably linked each other. When forming an organization's portfolio, it is necessary to define a system of criteria for evaluating the organization's goals and a procedure for selecting portfolio items. The portfolio of projects should include only those projects that are consistent with the company's sustainable development strategy and satisfy resource constraints. For a holistic view of the methodology for the formation of a value-oriented portfolio of projects, we consider each of the stages of the presented algorithm in the form of a block diagram (Fig. 1).

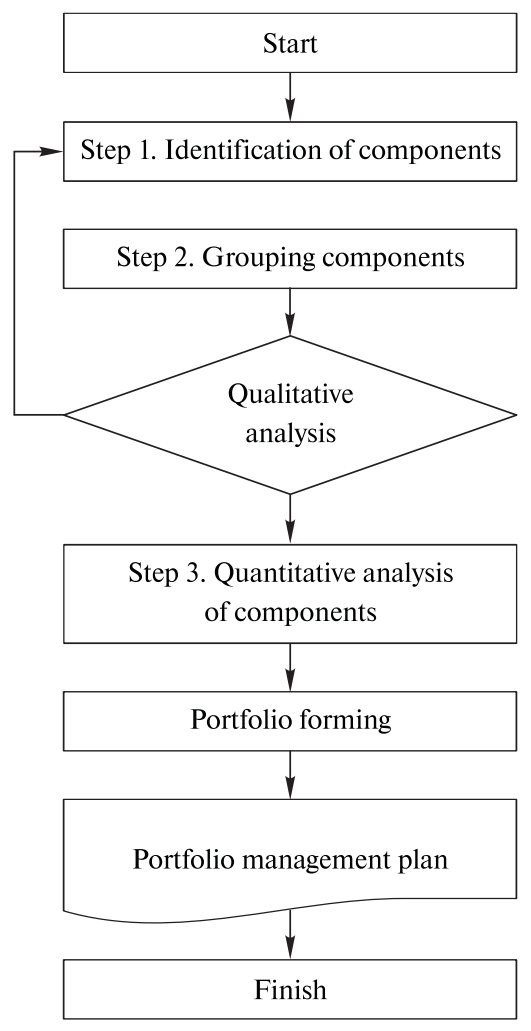

Fig. 1. Block diagram of the algorithm for forming the projects portfolio 
Stage 1. Identification of the portfolio components. A list of potential portfolio components is being formed. The components of the portfolio can be initiatives, projects, programs, sub-portfolios. At the same time, it is difficult to combine financial efficiency and strategic development prospects [14]. For example, a very profitable project from the point of view of finance introducing a new technology or a new product could, on a company-wide scale, can lead to a steady growth in the value of the company in the future. Therefore, before starting to form a portfolio of projects, preliminary review of all project initiatives is conducted and knowingly inefficient projects reject, which reduces the number of alternatives in each area of the activity.

To develop project proposals and integrate detailed plans into the overall development portfolio plan, it is advisable to involve experts with experience in the practical implementation of innovative technologies. Since at every enterprise, in every division, there are mid-level managers with experience in planning their site, using their experience in the planning of innovative projects is an effective means of creating internal organizational knowledge. The collection and analysis of data on project proposals was conducted using the method of questioning the managers of the enterprise after the introductory session.

It should be borne in mind that when planning the implementation of innovative projects, the result of which will be the release of a certain range of innovative products, the metallurgical enterprise should also form a portfolio of intellectual property rights objects that will make it possible to protect the entire list of such products. In this case, we are talking about the legal protection of the results of scientific and technical activities, representing the scientific and technical potential of the enterprise.

Stage 2. Grouping of projects. Projects are divided into groups that characterize work processes, managerial structures, team intelligence and information technology. Projects of one portfolio category have a corresponding set of criteria. Separation of projects into groups allows linking projects to specific goals. However, this also requires the experience and knowledge of middle managers. Each of the specific technology managers gave an evaluation with the help of special coding, the values of which are given further: $E E$ - activities that improve energy efficiency and reduce greenhouse gas emissions; $E X$ - technologies, already applied at many enterprises to competitors; $N$ - technology is suitable only for application in new enterprises; $P$ - advanced technology, is still in the research or verification stage; $S$ - specialized technologies, partially applicable in the enterprise; $C$ - the enterprise already uses this technology, but not enough.

The proposed characteristics of the best technologies for the enterprise were used in components of the development portfolio for the technical re-equipment of the enterprise.

With the proposed technology coding, project managers can evaluate the completeness of information support for an innovation project or program and take into account the risks that this causes. The manager will be able to show the percentage of information insecurity of the project and plan work on further research. In addition, such a technique allowed discussing risky projects or activities with the leadership, pointing out their weaknesses.

The final analysis of project proposals made it possible to create a database on innovative projects for the introduction of the best metallurgical technologies and to assess their suitability for the characteristics of the enterprise. To this end, with respect to each innovation technology, mid-level managers who received training were assessed on a three-point scale "low" or 1, "medium" or 2, "high" or 3. The summarized results of the work performed at the metallurgical enterprise are given in Table 1.

Quantitative analysis is designed to rank the priorities of projects in terms of their value for the company. The result of
Table 1

Characteristics of the enterprise innovative technologies

\begin{tabular}{|l|c|c|}
\hline \multicolumn{1}{|c|}{ Technological site } & $\begin{array}{c}\text { Balls } \\
1-3\end{array}$ & Code \\
\hline Utilization of the heat of aggloms & 3 & $C$ \\
\hline Reduction of air inflow & 2 & $C$ \\
\hline Utilization of waste fuels and oils during sintering & 3 & $C, S$ \\
\hline Moisture control of coal & 1 & $C, E X$ \\
\hline Better heating control of charge & 3 & $C, E X$ \\
\hline Compression of coke oven gas & 1 & $C$ \\
\hline Dry quenching of coke & 1 & $C$ \\
\hline The use of excess coke gas & 2 & $C, E X$ \\
\hline Single-chamber reactor with coal heating & 2 & $C, N$ \\
\hline Coke oven with combustion of gaseous products & 2 & $C, E X$ \\
\hline Injection of natural gas 140 $\mathrm{m}^{3} / \mathrm{t}$ of cast iron & 3 & $C, E X$ \\
\hline Injection of fuel oil & 2 & $C$ \\
\hline Injection of coke oven and converter gas & 3 & $C$ \\
\hline Use of superfluous pressure of top gas & 2 & $N, S$ \\
\hline Automation of air heaters & 3 & $E X$ \\
\hline Utilization of heat of slag & 1 & $P$ \\
\hline Recycling of blast furnace gas & 2 & $P$ \\
\hline Use of heat of converter gas & 2 & $C$ \\
\hline Improved heating of the ladle & 2 & $C, E X$ \\
\hline
\end{tabular}

the selection and evaluation phase is the list of projects recommended for inclusion in the portfolio.

Stage 3. Evaluation and selection of projects. At this stage, criteria and weighted indicators are developed for each group of projects. The task of evaluating and selecting projects in the portfolio is based on a quantitative analysis of portfolio projects.

Projects of each group have a corresponding set of criteria, and estimates can be based on a system of conditional metrics or weights. The methods of qualitative and quantitative analysis make it possible to include in the portfolio only significant and profitable projects for the company that meet its strategic goals.

The paradigm of sustainable development made it possible to identify the system components of scientifically based ideas about the purpose, priorities, content and means of economic activity of the enterprise on the basis of harmonization of economic, environmental and social interests. The conceptual model of sustainable development project portfolio for the metallurgical enterprise proposes three main components characterizing the economic state of the enterprise, its technological equipment and its impact on the environment.

Each of the three components of the control system is a subsystem that contains its own criterial indicators (Table 2).

At present, there are no general and verified methodologies for the development of a conceptual domain model. Among the general questions concerning modeling, some fundamental rules are singled out and usually offer one of the possible ways of developing the subject area.

The basic principle of the hierarchy method is based on the fact that for practical purposes the system is considered in terms of its structure and goals. A hierarchy is a certain graphic depiction of the structure of the goals of the system, designed to study the interconnections of its components and their effects on the system as a whole. If, in order to simplify the task, the elements in each group of the hierarchy are recognized as independent, then the assessment of solution options by the hierarchy analysis method reduces to the following: 
Criteria for the selection of projects in sustainable development portfolio

\begin{tabular}{|c|c|}
\hline Characteristic & Index \\
\hline \multirow[t]{5}{*}{ Economy } & E 1. Economic benefit of projects \\
\hline & E 2. Financial stability of the enterprise \\
\hline & E 3. Payback rate \\
\hline & E 4. Capacity of the market of innovative products \\
\hline & E 5. The state of the resource base \\
\hline \multirow[t]{5}{*}{ Technologies } & $\mathrm{T} 1$. Technological equipment of sinter plant \\
\hline & T 2. Re-equipment of coke-chemical production \\
\hline & T 3. Development of blast-furnace production \\
\hline & T 4. Development of oxygen-converter production \\
\hline & T 5. Development of innovative projects \\
\hline \multirow{5}{*}{$\begin{array}{l}\text { External } \\
\text { environment }\end{array}$} & BC 1 . The state of the market \\
\hline & BC 2. The emergence of innovative products \\
\hline & BC 3. New tools of competition \\
\hline & BC 4. Adaptive price policy \\
\hline & BC 5. Competence and competitive advantages \\
\hline
\end{tabular}

1. The system represented as a hierarchy, which displayed by the tree of related elements.

2 . The input information for the calculations is the matrices of paired comparisons of the priorities of the lower-level elements of the hierarchy in terms of top-level elements, determined by experts.

3. Using the matrices of paired comparisons, the relative priority vector is calculated, which is an eigenvalue vector of the judgment matrix.

When creating such a conceptual model of enterprise development in a particular subject field, information concerning properties, relations, constraints, axioms and statements for describing the problem in terms of the subject area is needed. Actually, modeling is preceded by work to determine the structural characteristics of the domain. As a rule, in this case, the source of information is expert judgments and documents from different institutions, which reflect the financial, technological, personnel and other aspects of the functioning of the organization.

The modern methodology for describing goals is based on the use of decomposition methods, deductive and inductive tools. However, many goals by their nature cannot be uniquely formalized, that is, they cannot be measured accurately. In such cases, subjective expert judgment is usually used. However, subjective information is determined by individual and collective consciousness, acquired as a result of observation and participation in the processes of the functioning of the system. It is in the form of giving special advantages to individual values. These advantages or disadvantages are often systematized and constantly changing in time, therefore it is not possible to formalize them in a numerical form.

The method of analyzing hierarchies is a systematic procedure of hierarchical representation of elements that determine the essence of any problem. The method consists in decomposing the problem into increasingly simpler constituent parts and further processing the sequence of statements of decision makers using paired comparisons. To represent the results of the assessment in quantitative terms, a scale of paired comparisons is introduced (Table 3 ).

Thanks to this method, it is possible numerically represent the relative degree of interaction in the hierarchy according to the provided scale. In this case, experts should not be bothered by the lack of physical or objective units of measurement.
Pairwise Comparison Scale

\begin{tabular}{|c|l|l|}
\hline Scores & \multicolumn{1}{|c|}{ Definitions } & \\
\hline 1 & Equal importance & $\begin{array}{l}\text { Both elements make the same } \\
\text { contribution }\end{array}$ \\
\hline 2 & $\begin{array}{l}\text { One element is slightly } \\
\text { better than another }\end{array}$ & $\begin{array}{l}\text { Experience allows you to put one } \\
\text { element just above the second }\end{array}$ \\
\hline 3 & Essential advantage & $\begin{array}{l}\text { Experience allows you to } \\
\text { establish the absolute advantage } \\
\text { of one over the other }\end{array}$ \\
\hline 4 & Significant advantage & $\begin{array}{l}\text { One element is more important } \\
\text { than the other }\end{array}$ \\
\hline 5 & Absolute advantage & $\begin{array}{l}\text { The evidence of advantage is } \\
\text { confirmed by the majority }\end{array}$ \\
\hline
\end{tabular}

The main advantage of this method is that it is dimensionless and there are no problems when reducing to the same units of measurement. Thus, the method includes the procedure for synthesizing many statements, obtaining priority criteria and finding alternative solutions. It is important that the values thus obtained are numerous estimates in the relationship scale.

The first step of the method is to decompose and present the strategy of sustainable development of the metallurgical enterprise in a hierarchical form. We consider the dominant hierarchies that are built from the top (the main goal) through intermediate levels to the lowest level, which is, as a rule, a list of possible alternatives. A hierarchy is considered complete if every element of a given level functions as a criterion for those elements of the level below. The law of hierarchical continuity requires that the elements of the lower level be pairwise equalized with respect to the elements of the next level and so on to the top of the hierarchy.

The main solution to the problem is the process of step-bystep formation of priorities. At the first stage, the most important elements of the problem are identified, the second is the best way to verify the statements and evaluate the elements. The entire process is subject to verification and re-evaluation until it is established that it has captured all the important characteristics of the main objective.

The second stage of the method of hierarchy analysis is the construction of matrices of paired comparisons for each of the lower levels. Elements of any level are compared with each other relative to their influence on the element of the higher level. According to the rule, when comparing matrices, the relative importance of the left elements of the matrix with the elements at the top is compared, if the element on the left is more important than the element at the top, then a positive integer is entered in the cell - fractional. The relative importance of any element is compared with itself, is equal to one. The matrix of judgments is added in such a way that if the priority of the $i^{\text {th }}$ object before the $j^{\text {th }}$ is $a_{i j}$, then the priority of the $j^{\text {th }}$ object before the $i^{\text {th }}$ is $l / a_{i j}$. A general example of the formation of the matrix of paired comparisons for the $E_{i}$ criteria is shown in Fig. 2.

From priority vectors that evaluate the effect of $i+1$-level elements on each $i$-level element associated with it, a priority

$[E]=$\begin{tabular}{|c|c|c|c|c|}
\hline & $E_{1}$ & $E_{2}$ & $\ldots$ & $E_{n}$ \\
\hline$E_{1}$ & $V_{1} / V_{1}$ & $V_{1} / V_{2}$ & $\ldots$ & $V_{1} / V_{n}$ \\
\hline$E_{2}$ & $V_{2} / V_{1}$ & $V_{2} / V_{2}$ & $\ldots$ & $V_{2} / V_{n}$ \\
\hline$\ldots$ & $\ldots$ & $\ldots$ & $\ldots$ & $\ldots$ \\
\hline$E_{n}$ & $V_{n} / V_{1}$ & $V_{n} / V_{2}$ & $\ldots$ & $V_{n} / V_{n}$ \\
\hline
\end{tabular}

Fig. 2. An example of a matrix of pairwise congruences 
matrix is generated that is multiplied by the priority vector obtained at the $i^{\text {th }}$ level of the hierarchy and the priority vector of $i+1$ level is obtained. In the general matrix of priorities of the third level of the hierarchy there will be as many columns as there are elements at the same level, and there will be as many rows as there are elements on the lower level. The performed calculations make it possible to assign the corresponding weight coefficient, which represents their significance from the point of view of the expert group, to each development priority. If the task is to choose one of the alternative solutions, then the option with the highest priority should be given preference.

The integral estimation of project value is determined taking into account the relative importance of certain values and calculated by the formula

$$
V=\sum_{i=1}^{I} V_{i n} g_{i n},
$$

where $V_{\text {in }}$ is scores for the value of a particular component of the portfolio; $g_{\text {in }}$ is the weight of the relative importance of the value of the portfolio component in accordance with the priority criteria for this strategy.

The weighting coefficient $g_{\text {in }}$ of the relative importance of the value of the portfolio component is determined by the expert method, for example, in the range from 0 to 1 . Preliminary work to determine development priorities makes it possible to assign each project an appropriate weighting coefficient, which represents its significance from the point of view of the expert group. Thus, the complex problem of transformation of the value-oriented strategy of the organization's development into the necessary components of the portfolio is solved in the sequence of certain stages of calculations of the corresponding system model.

In general, the problem of finding the optimal portfolio of projects can be written

$$
V_{k}=\sum_{i=1}^{n} c_{i} x_{i} ; \quad \sum_{i=1}^{n} a_{i j} x_{i} \leq B_{i} ; \quad \sum_{i=1}^{n} x_{i} \leq P,
$$

where $V_{i n}$ is the criterion of the value of the portfolio, $B_{i}$ is the existing volume of the resource $R_{i}, a_{i j}$ is the volume of the $i^{\text {th }}$ resource required to execute the $j^{\text {th }}$ project, $P$ is the maximum number of projects in the portfolio. If $x_{i}=1$, then the project enters the portfolio, if $x_{i}=0$, then not.

The process of project evaluation and selection is a key element of strategic activity. To create a sustainable enterprise development portfolio, the organization must recognize what the stakeholders of the enterprise expect and what the expected values of investment projects are, evaluate them financially, then combine the experience, information, data and other resources that the organization owns to create and launch a sustainable development portfolio. In connection with the incompleteness of information, it is not possible to consider all innovative projects simultaneously. They have to be evaluated consistently. In the beginning, you can create a portfolio of projects that will have only one project from each subset.

The portfolio has to maximize the useful result, minimize the risk and meet all the constraints and requirements. The proposed methodology allows transforming the strategy of sustainable development into the formation of key indicators of the achievement of the goal. The main thing in this formulation of the scientific task is to learn how to model the desired future through the subjective attitude of experts, since the decision-maker consciously or subconsciously creates a picture of the world passed through his own filters.

Conclusions. In the process of modeling the portfolio management of the metallurgical enterprise, the following scientific results were obtained:

1. The development portfolio model is developed that combines three elements in interaction: economy, technology and analysis of the external environment. Each of these ele- ments is characterized by five benchmarks. On the basis of the hierarchy analysis method, it is reasonable to estimate each of the potential components of the portfolio to justify their inclusion in the portfolio by an integrated assessment.

2 . The sequence of stages of the methodology for selecting projects in the portfolio of sustainable development of a metallurgical enterprise is described. To determine the innovativeness of projects, criteria are proposed that characterize their suitability for the characteristics of the enterprise.

3. For the formation of the base of the project proposals, the staff of the middle management of the metallurgical enterprise was trained. After carrying out preliminary studies, the base of project proposals for the sustainable development portfolio of the enterprise was formed.

The balancing of the portfolio components, taking into account their possible dependence in the development portfolio, will be considered in the following publications.

\section{References.}

1. Strategy for sustainable development of Ukraine until 2030. (2019). Retrieved from https://www.undp.org/content/dam/ ukraine/docs/SDGreports/UNDP_Strategy_v06-optimized. pdf.

2. Carley, M., \& Christie, I. (2017). Managing sustainable development. Routledge. https://doi.org/10.4324/9781315091525.

3. Sachs, J. D. (2015). The age of sustainable development. Columbia University Press. https://doi.org/10.7312/sach17314.

4. Hvesik, M. A. (2019). Environmental Economics: Development Vectors. Kyiv: PI IEESD of the NAS of Ukraine.

5. Kuzminov, A., Korostieva, N., \& Filippov, S. (2016). The Extension Model of Sustainable Management of Industrial Enterprises. Journal Of Economic Regulation, 7(3), 65-77. https://doi.org/10.17835/2078-5429.2016.7.3.065-077.

6. Weaver, P., Jansen, L., Grootveld, G., Spiegel, E., \& Vergragt, P. (2017). Sustainable Technology Development. Routledge. https://doi.org/10.4324/9781351283243.

7. Kivilä, J., Martinsuo, M., \& Vuorinen, L. (2017). Sustainable project management through project control in infrastructure projects. International Journal Of Project Management, 35(6), 1167-1183. https://doi.org/10.1016/j.ijproman.2017.02.009.

8. Pererva, P. G., \& Romanchik, T.V. (2018). Innovation as the factor of economic safety of industrial production. In Illyashenko, S. M., \& Bilodovska, O.A. (Eds.) (2018). Instruments and Methods of Innovation Products: Monograph. Sumi: Tritoria, 56-74.

9. Bluszcz, A., \& Kijewska, A. (2015). Challenges of sustainable development in the mining and metallurgy sector in Poland. Metalurgija, 54(2), 441-444.

10. Nistor, C., \& Herman, R. (2015). Metallurgy-an industry between traditional and sustainable management. Manager, (24), 81-96.

11. Zablodska, I. V., \& Ivchenko, E. A. (2015). Foresight as an in-tool for diagnosing the development of the metallurgical complex of Ukrainian regions. News of the Ukrainian-Ukrainian National University of Volodymyr Dahl, (6), 39-41.

12. Furdichko, L. E., \& Skvarko, Yu. V. (2016). The current state and prospects of the metallurgical galaxy of Ukraine: financial indicators of development, export-import products. Social-economic problems of the current period of Ukraine, (3), 102-106.

13. Demidenko, M. (2017). Economic and mathematical model of optimal pricing of suppliers and processors of raw materials for sustainable development of the mining and metallurgical complex of Ukraine. International Scientific Conference Anti-Crisis Management: State, Region, Enterprise: Conference Proceedings, Part III, November 17 ${ }^{\text {th }}$, (pp. 141-142).

14. Sukhomlin, L. V., \& Orlova, K. O. (2017). Strategic Planning as a Method of Steel Development of the Metal Industry. Materials of the $5^{\text {th }}$ National Science Conference "Actual Problems and Prospects for the Development of the Economy in the Thoughts of Global Instability”, (pp. 143-144). Kremenchuk. Retrieved from 
http://www.kdu.edu.ua/conf fin/materials 2017. pdf $\#$ page $=143$.

\section{Формування портфелю сталого розвитку металургійного підприємства 3 використанням методу аналізу ієрархій}

\section{В. М. Молоканова ${ }^{1}$, О. П. Орлюк ${ }^{2}$, В. О. Петренко ${ }^{3}$, О. Б. Бутнік-Сіверський ${ }^{2}$ В. Л. Хоменко}

1 - Дніпропетровський регіональний інститут державного управління Національної академії державного управління при Президенті України, м. Дніпро, Україна, e-mail: molokany@gmail.com

2 - Науково-дослідний інститут інтелектуальної власності НАПрН України, м. Київ, Україна, e-mail: e.orliyk@ ndiiv.org.ua, busiv@ukr.net

3 - Національна металургійна академія України, м. Дніпро, Україна, e-mail: petrenko_v@email.ua

4 - Національний технічний університет «Дніпровська політехніка», м. Дніпро, Україна, e-mail: inteldriller@ gmail.com

Мета. Формалізація основних етапів і методів формування портфелю проектів металургійного підприємства 3 урахуванням стратегії його сталого розвитку.

Методика. Для характеристики кожного елементу й наступного представлення відповідного вагового показника, на основі якого буде виконуватися відбір компонентів портфелю, застосовується класичний метод аналізу ієрархій. Цей метод дозволяє оцінити пріоритети сталого розвитку підприємства відносно до його генеральної мети.

Результати. Розроблена модель портфелю розвитку, що об'єднує у взаємодії три елементи: економіку, технології та аналіз зовнішнього середовища. Кожний із цих елементів охарактеризований п'ятьма критеріальними показниками. На основі методу аналізу ієрархій обгрунтована оцінка кожного з потенційних компонентів для включеннях їх у портфель за інтегральною оцінкою. Описана послідовність етапів методики відбору проектів у портфель сталого розвитку металургійного підприємства. Для визначення іноваційності проектів запропоновані критерії, що характеризують їх придатність.

Наукова новизна. Розроблена принципово нова модель портфелю розвитку, що об'єднує у взаємодії три елементи: економіку, технології та аналіз зовнішнього середовища. Уперше запропоновані критерії для визначення іноваційності проектів, що характеризують придатність технологій з урахуванням особливостей підприємства. Представлено новий метод формування портфелю розвитку підприємства з використанням методу аналізу ієрархій.

Практична значимість. У результаті проведення досліджень задля формування бази проектних пропозицій було проведено експериментальне навчання персоналу середньої управлінської ланки металургійного підприємства. Після проведення попередніх занять була сформована база проектних пропозицій для портфелю сталого розвитку підприємства.

Ключові слова: сталий розвиток, металургійне підприємство, портфель проектів, метод аналізу ієрархій

\section{Формирование портфеля устойчивого развития металлургического предприятия с использованием метода анализа иерархий}

\author{
В. М. Молоканова ${ }^{1}$, Е. П. Орлюк ${ }^{2}$, В. А. Петренко ${ }^{3}$, \\ А. Б. Бутник-Сиверский ${ }^{2}$, В. Л. Хоменко ${ }^{4}$
}

1 - Днепропетровский региональный институт государственного управления Национальной академии государственного управления при Президенте Украины, г. Днепр, Украина, e-mail: molokany@gmail.com

2 - Научно-исследовательский институт интеллектуальной собственности НАПрН Украины, г. Киев, Украина, e-mail: e.orliyk@ndiiv.org.ua, busiv@ukr.net

3 - Национальная металлургическая академия Украины, г. Днепр, Украина, e-mail: petrenko_v@email.ua

4 - Национальный технический университет «Днепровская политехника», г. Днепр, Украина, e-mail: inteldriller@ gmail.com

Цель. Формализация основных этапов и методов формирования портфеля проектов металлургического предприятия с учетом стратегии его устойчивого развития.

Методика. Для характеристики каждого элемента и последующего представления соответствующего весового показателя, на основе которого будет выполняться отбор компонентов портфеля, применяется классический метод анализа иерархий. Этот метод позволяет оценить приоритеты устойчивого развития предприятия относительно к его генеральной цели.

Результаты. Разработана модель портфеля развития, объединяющая во взаимодействии три элемента: экономику, технологии и анализ внешней среды. Каждый из этих элементов охарактеризован пятью критериальными показателями. На основе метода анализа иерархий обоснована оценка каждого из потенциальных компонентов для включения их в портфель по интегральной оценке. Описана последовательность этапов методики отбора проектов в портфель устойчивого развития металлургического предприятия. Для определения инновационности проектов предложены критерии, которые характеризуют их пригодность.

Научная новизна. Разработана принципиально новая модель портфеля развития, объединяющая во взаимодействии три элемента: экономику, технологии и анализ внешней среды. Впервые предложены критерии для определения инновационности проектов, которые характеризуют применимость технологий с учетом особенностей предприятия. Представлен новый метод формирования портфеля развития предприятия с использованием метода анализа иерархий.

Практическая значимость. В результате проведения исследований для формирования базы проектных предложений было проведено экспериментальное обучение персонала среднего управленческого звена металлургического предприятия. После проведения предварительных занятий была сформирована база проектных предложений для портфеля устойчивого развития предприятия.

Ключевые слова: устойчивое развитие, металлургическое предприятие, портфель проектов, метод анализа иерархий

Recommended for publication by A. V. Bardas, Doctor of Economic Sciences. The manuscript was submitted 28.04.19. 